\title{
PELAKSANAAN HAK ASUH ANAK SETELAH TERJADINYA PERCERAIAN*
}

\author{
Umul Khair \\ Sekolah Tinggi Ilmu Hukum Putri Maharaja Payakumbuh \\ e-mail: umul.khair01@gmail.com
}

\begin{abstract}
Based on law, children under the age of ten, should be passed into their mother. Whereas for children over the age of ten have a right to choose, even though, in reality, they will be more is taken care of by their father. This study aims to find out how the implementation of child custody after the divorce occurred in the Jopang Manganti kenagarian?. In addition, the study was made to find out what obstacles arose in the implementation of child custody after the divorce took place in Jopang Manganti? As well as how is the solution to overcome the obstacles in the implementation of child custody after the divorce took place in Jopang Manganti? This study uses a sociological juridical approach which concludes that the implementation of child custody after the divorce in the Jopang Manganti religion is in fact incompatible with the decision of the religious court with the constraints. These constraints include: Lack of a sense of responsibility of the mother, the mental condition of the mother who is not ready to face divorce, lack of religious knowledge of the mother. The researcher also recommends that the solution to this obstacle is to give the mother an understanding of the responsibility that the child is entrusted by God. Another solution is to provide an understanding that not every divorce has a negative impact, increasing the understanding of religion that God has predestined. divorce.
\end{abstract}

Keywords: Implementation; Child Custody; Divorce.

\begin{abstract}
Abstrak
Anak yang berumur dibawah sepuluh tahun, perwaliannya diserahkan kepada ibunya. Sedangkan bagi anak yang berumur di atas sepuluh tahun terserah kepada pilihan si anak sendiri, namun kenyataannya anak tersebut diasuh oleh ayahnya. Rumusan masalah dari penelitian ini adalah: bagaimana pelaksanaan hak asuh anak setelah terjadinya perceraian di kenagarian Jopang Manganti? apa kendala-kendala dalam pelaksanaan hak asuh anak setelah terjadinya perceraian di kenagarian Jopang Manganti? dan apa solusi untuk mengatasi kendala-kendala dalam pelaksanaan hak asuh anak setelah terjadinya perceraian di kenagarian Jopang Manganti?. Metode penelitian ini adalah menggunakan pendekatan yuridis sosiologis. Sebagai kesimpulan dari penelitian ini adalah: pelaksanaan hak asuh anak setelah terjadinya perceraian di kenagarian Jopang Manganti pada kenyataannya tidak sesuai dengan putusan Pengadilan Agama dengan adanya kendalakendala, kendala Dalam Pelaksanaan Hak Asuh Anak Setelah Terjadinya Perceraian di Kenagarian Jopang Manganti adalah sebagai berikut: Kurangnya rasa tanggung jawab si Ibu, kondisi mental si Ibu yang tidak siap menghadapi perceraian, kurangnya pengetahuan agama si Ibu dan solusi terhadap kendala tersebut adalah: memberikan pemahaman kepada si Ibu akan rasa tanggung jawab bahwa anak tersebut adalah titipan Allah dan akan di pertanggungjawabkan, memberikan pemahaman bahwa tidak setiap perceraian membawa dampak negatif, meningkatkan pemahaman agama bahwa Allah telah mentaqdirkan perceraian.
\end{abstract}

Kata Kunci: Pelaksanaan; Hak Asuh Anak; Perceraian.

\footnotetext{
${ }^{*}$ Naskah diterima: 15 Februari 2020, direvisi: 23 Maret 2020, disetujui untuk terbit: 26 Maret 2019

Doi: $10.3376 /$ jch.v5i2.231
} 


\section{PENDAHULUAN}

Perkawinan merupakan awal dari hidup bersama antara seorang pria dan seorang wanita sebagaimana yang diatur dalam peraturan perundang-undangan yang berlaku. Perkawinan adalah hubungan hukum yang merupakan pertalian yang sah antara seorang laki-laki dan seorang wanita yang telah memenuhi syarat-syarat perkawinan untuk jangka waktu selama mungkin

Kompilasi Hukum Islam mengatur tentang pemeliharaan anak pasca putusnya hubungan perkawinan orang tua dalam Pasal 105 yang menyatakan dalam hal terjadinya perceraian: 1 . Pemeliharaan anak yang belum mumayiz atau belum berumur 12 tahun adalah hak ibunya; 2 . Pemeliharaan anak yang sudah mumayiz diserahkan kepada anak untuk memilih di antara ayah atau ibunya sebagai pemegang hak pemeliharaannya; 3. Biaya pemeliharaan ditanggung oleh ayahnya.

Menurut Undang-Undang Nomor 16 Tahun 2019 tentang Perubahan Atas Undang-Undang Nomor 1 Tahun 1974 Pasal (2) disebutkan bahwa "perkawinan adalah sah apabila dilakukan menurut hukum masing-masing agamanya," kemudian mengenai pencatatannya diatur dalam PP Nomor 9 Tahun 1975 yaitu "pencatatan perkawinan dari mereka yang melangsungkan perkawinannya menurut agama Islam, dilakukan oleh PPN sebagaimana dimaksud dalam Undangundang Nomor 32 Tahun 1954 tentang Pencatatan Nikah, Talak, dan Rujuk.8 Sehingga, Peradilan Agama dalam hal perkawinan mempunyai kewenangan absolut mengenai proses perceraian dan pencatatannya, sedangkan pengawasan dan pencatatan perkawinannya merupakan kewenangan Kantor Urusan Agama (KUA) yang dikepalai oleh Pegawai Pencatat Nikah. (Ani Yumarni, 2019)

Anak-anak yang belum dewasa dan tidak dibawah kekuasaan orang tua harus ditaruh di bawah perwalian menurut sistem Burgerlijk Wetboek. Setelah pihak orang tua bercerai pun harus diadakan persediaan mengenai perwalian dari anak-anak mereka yang masih di bawah umur. (Fauzi, 2018)

Sebelum berlakunya Undang-undang Perkawinan Nomor 1 Tahun 1974 tentang Perkawinan, di Indonesia terdapat beraneka ragam hukum Perkawinan yang berlaku bagi berbagai golongan penduduk dari berbagai daerah,

1. Bagi orang-orang Indonesia asli yang beragama Islam berlaku hukum agama yang telah diresepir dalam hukum adat.

2. Bagi orang-orang Indonesia asli lainnya, berlaku hukum adat.

3. Bagi orang-orang Indonesia Asli yang beragama Kristen berlaku Huwelijke Ordonantie Christen Indonesia.

4. Bagi orang-orang Timur Asing lainnya, dan warga Negara Indonesia keturunan Cina berlaku ketentuan kitab undang-undang hukum perdata dengan sedikit perubahan.

5. Bagi orang-orang Eropa dan warga Negara Indonesia keturunan Eropa dan yang disamakan dengan mereka 
berlaku Kitab Undang-Undang Hukum Perdata. (Mulyadi,1996)

Masalah mengenai hak asuh anak ini, bagi warga Indonesia asli berlaku hukum adatnya masing-masing. Adapun dalam Undang-Undang, hak asuh anak bila terjadi perceraian orang tua sudah dijelaskan dalam beberapa pasal. Diantaranya pasal 45 ayat (2), pasal 98, dan pasal 105. Dengan adanya dasar hukum dan Undang-undang yang mengatur, diharapkan anak tetap sejahtera dan tumbuh sebagaimana mestinya meskipun orang tuanya berpisah. Walaupun secara jelas sudah dicantumkan dalam pasal 10a) Kompilasi Hukum Islam (KHI) bahwa: Pemeliharaan anak yang belum mumayyiz (dibawah 1 tahun) menjadi hak ibunya. Jika anak tersebut sudah dewasa, maka diserahkan kepada keputusan anak tersebut apakah memilih bersama ibunya atau bersama ayahnya.

Dalam istilah fiqh digunakan dua kata namun ditunjukkan untuk maksud yang sama yaitu kafalah atau hadhanah. Yang dimaksud dengan hadhanah atau kafalah dalam arti yang sederhana, ialah “ pemeliharaan atau pengasuhan “. Dalam arti yang lebih lengkap, adalah pemeliharaan anak yang masih kecil setelah terjadinya putusnya perkawinan. Hal ini dibicarakan dalam fiqih, karena secara praktis antara suami isteri telah terjadi perpisahan, sedangkan anak-anak masih memerlukan bantuan dari ayah atau ibunya. (Amir Syarifuddin, 2006)

Dalam pasal 156 huruf (c) Kompilasi Hukum Islam (KHI) disebutkan apabila pemegang hak asuh anak (hadhanah) ternyata tidak dapat menjamin keselamatan jasmani dan rohani anak, meskipun biaya nafkah dan hadhanah telah dicukupi, maka atas permintaan kerabat yang bersangkutan Pengadilan agama dapat memindahkan hak asuh anak (hadhanah) kepada kerabat lain yang mempunyai hak asuh anak (hadhanah).

Berdasarkan analisa awal penulis dan pada umumnya, anak yang berumur dibawah sepuluh tahun, pengasuhnya atau perwaliannya diserahkan kepada ibunya. Sedangkan bagi anak yang berumur di atas sepuluh tahun terserah kepada pilihan si anak sendiri, apakah dia akan ikut kepada ibunya ataukah memilih ikut pada bapaknya dalam hal hak asuh bagi anak. Apabila hal yang demikian ini terjadi maka putusan pengadilan yang menentukan siapakah yang lebih berhak menjadi hak asuh anak tersebut.

Namun dalam kenyataannya di Kenagarian Jopang Manganti Kabupaten Lima Puluh Kota, penulis menemukan dan mengamati seorang anak yang diasuh oleh ayahnya sedangkan hak asuh anak setelah terjadi perceraian putusan agama Kabupaten Lima Puluh Kota jatuh pada Ibu, tapi ibu tersebut melepaskan tanggung jawabnya terhadap anak. Mulai dari sang anak berumur dibawah lima tahun sampai sekarang anak sudah menginjak remaja.

\section{METODE PENELITIAN}

Dalam penelitian ini penulis menggunakan metode pendekatan yuridis sosiologis yang berdasarkan ketentuan- 
ketentuan perundang-undangan yang berlaku dikaitkan dengan teori hukum serta melihat realita yang terjadi di masyarakat yaitu berkaitan dengan hak asuh anak setelah terjadinya perceraian di Kenagarian Jopang Manganti Kabupaten Lima Puluh Kota.

Pelitian ini bersifat Deskriptif, yaitu penelitian yang memberikan data tentang sesuatu atau gejala-gejala sosial yang berkembang di tengah-tengah masyarakat sehingga dengan adanya penelitian ini diharapkan dapat memperoleh gambaran yang menyeluruh, lengkap dan sistematis tentang objek yang akan di teliti.

Setelah semua data berhasil dikumpulkan berdasarkan penelitian yang dilakukan di lapangan, maka data tersebut disatukan untuk kelanjutan diolah sedemikian rupa secara sistematik. Untuk itu digunakan analisa kualitatif, yaitu hasil penelitian kepustakaan akan dipergunakan untuk menganalisa data yang diperoleh dari lapangan dan kemudian data primer dan data sekunder dianalisa secara kualitatif untuk menjawab permasalahan dalam penelitian ini.

Dari bahan dan data yang telah terkumpul dari penelitian tersebut di atas, maka penulis akan menganalisa secara deskriptif yakni membandingkan antara teori dengan prakteknya di lapangan, sehingga diperoleh suatu kesimpulan yang induktif, yaitu suatu kesimpulan dari yang khusus kepada yang umum.

\section{HASIL DAN PEMBAHASAN}

\section{Pelaksanaan Hak Asuh Anak Setelah Terjadinya Perceraian di Kenagarian Jopang Manganti kabupaten Lima Puluh Kota}

Berdasarkan hasil wawancara dengan Desti Suryani sebagai pelaku perceraian tentang pelaksanaan hak asuh anak setelah terjadinya perceraian di kenagarian Jopang Manganti adalah sebagai berikut:

1. Perceraian yang terjadi antara pasangan suami isteri bernama Dodi dengan Desti Suryani berdasarkan pada putusan Pengadilan Kabupaten Lima Puluh Kota tahun 2009 dan diajukan oleh isteri (cerai gugat)

2. Mengenai Hak asuh anak pada putusan Pengadilan Agama tersebut jatuh kepada Si Ibu, yang mana anak tersebut baru berusia 4 Tahun.

Berdasarkan pada kenyataannya walaupun hak asuh anak jatuh pada si Ibu, tapi anak diserahkan oleh si Ibu kepada ayahnya dengan cara dititipkan saja pada sopir dari mantan suami tanpa sebab yang jelas. Hal ini tidak sesuai dengan putusan Pengadilan Agama Tanjung Pati Kabupaten Lima Puluh Kota juga tidak sesuai dengan Inpres Nomor 1 Tahun 1991 tentang Kompilasi Hukum Islam (KHI) Pasal 105 menyebutkan bahwa dalam hal terjadinya perceraian: maka pemeliharaan anak yang belum mumayyiz atau belum berumur 12 tahun adalah hak ibunya. (Maswandi, 2017)

Menurut Pasal 26 KUH Perdata Tentang Perkawinan menyatakan 
perkawinan adalah pertalian yang sah antara seorang laki-laki dan seorang perempuan dalam waktu yang lama. Undang-undang memandang perkawinan hanya pada hubungan keperdataan, yang artinya bahwa suatu perkawinan yang sah, hanyalah perkawinan yang memenuhi syarat-syarat yang ditetapkan dalam KUH Perdata.

Di dalam KUH Perdata Pasal 199 menyatakan tentang bubarnya perkawinan itu dibedakan menjadi 4 (empat) macam, yaitu:

1. Kematian salah satu pihak.

2. Tidak hadirnya suami-istri selama 10 tahun dan diikuti perkawinan baru

3. Adanya putusan hakim Perceraian Perceraian ialah penghapusan perkawinan dengan putusan hakim,

4. Tuntutan salah satu pihak dalam perkawinan itu. (Hariyani, 2016)

Jika terjadi perceraian tidak ada kewajiban untuk hidup bersama lagi. Dalam Undang-Undang Nomor 1 Tahun 1974 tentang Perkawinan hal ini tidak diatur, tetapi kita dapat melihat ketentuannya dalam Peraturan Pemerintah Nomor 9 Tahun 1974 yang merupakan peraturan pelaksanaan dari UndangUndang Nomor 1 Tahun 1974, yaitu Pasal 24 ayat (1) yang menyatakan bahwa:

Selama berlangsung gugatan
perceraian, atas permohonan
penggugat atau tergugat berdasarkan
pertimbangan bahaya yang mungkin
ditimbulkan, pengadilan dapat
mengizinkan suami istri tersebut
untuk tidak tinggal dalam satu rumah

lagi tujuannya untuk mencegah agar tidak terjadi bahaya yang timbul apabila suami istri tinggal satu rumah lagi.

Mengenai akibat hukum putusnya perkawinan karena perceraian terhadap suami istri tidak diatur secara rinci. Hanya ada satu pasal yang mengatur yaitu pasal 41 Huruf C Undang-undang Nomor 1 Tahun 1974, yang berbunyi:

"Pengadilan dapat mewajibkan kepada bekas suami untuk memberi biaya penghidupan dan/atau menentukan sesuatu kewajiban bagi bekas istrinya'.

Menentukan sesuatu kewajiban ini harus berdasarkan hukum. Adanya anak dalam suatu pernikahan merupakan hal yang diimpikan oleh setiap pasangan. Bagi mereka anak merupakan karunia Tuhan yang luar biasa, dia wajib dijaga dan dirawat sebaik-baiknya. Persoalan akan muncul di kala pernikahan yang telah terjalin putus dengan berbagai alasan yang pada akhirnya dibenarkan oleh pengadilan dengan membacakan putusan cerai. Pada saat putusnya perkawinan karena bercerainya suami istri, mau tidak mau anak menjadi korban.

Secara yuridis, kedudukan anak dalam perkawinan diatur dalam Pasal 42 Undang-undang Nomor 1 Tahun 1974 tentang Perkawinan yang memuat ketentuan definitif bahwa anak yang sah adalah anak yang dilahirkan dalam atau sebagai akibat perkawinan yang sah. Kemudian, menurut ketentuan limitatif dalam Pasal 43 ayat (1) Undang-Undang Nomor 1 Tahun 1974 tentang 
Perkawinan, anak yang dilahirkan diluar perkawinan hanya mempunyai hubungan perdata dengan ibunya dan keluarga ibunya. Ini berarti bahwa Undang-undang Nomor 1 Tahun 1974 tentang Perkawinan Pasal 45 ayat (1) dan ayat (2) memuat ketentuan bahwa kedua orang tua wajib memelihara dan mendidik anak mereka sebaik-baiknya. Kewajiban tersebut berlaku sampai anak itu kawin atau dapat berdiri sendiri, kewajiban mana berlaku terus meskipun perkawinan antara kedua orang tua putus.

Menurut Pasal 229 Kitab UndangUndang Hukum Perdata, pengadilan menentukan wali anak dibawah umur. Apabila pihak yang diserahkan sebagai wali kurang mampu membiayakan pemeliharaan dan pendidikan anak, maka menurut pasal 230 Kitab Undang-undang Hukum Perdata maka hakim dapat menentukan jumlah uang yang harus dibayar pihak yang lain untuk membiayai anak yang dibawah umur.

Menurut Undang-Undang Perkawinan Nomor 1 Tahun 1974 pasal 41 antara lain:

Baik ibu atau bapak wajib memelihara dan mendidik anakanaknya, semata-mata berdasarkan kepentingan anak, bilamana ada perselisihan mengenai penguasaan anak-anak, pengadilan memberikan keputusan.

Biaya pemeliharaan dan pendidikan anak-anak menjadi tanggung jawab pihak bapak, kecuali dalam pelaksanaan pihak bapak tidak dapat melakukan kewajiban tersebut, maka pengadilan dapat menentukan bahwa ibu dapat memikul biaya tersebut. Akan tetapi bilamana pihak bapak dalam kenyataannya tidak dapat memenuhi kewajiban tersebut, pengadilan dapat menentukan bahwa ibu dapat ikut memikul biaya tersebut. Kecuali itu pengadilan dapat pula memberikan keputusan tentang siapa diantara mereka berdua yang berhak anak yakni memelihara dan mendidiknya, apabila terjadi perselisihan antara keduanya. Keputusan pengadilan ini juga tentu berdasarkan kepentingan anak.

Hak asuh anak setelah perceraian ini tidak diatur di dalam Undang-Undang Nomor 1 tahun 1974 tentang Perkawinan. Tidak ada kata yang spesifik dalam ketentuan tersebut yang mengatakan hak asuh anak. Undang-Undang Nomor 1 tahun 1974 tentang Perkawinan mengatakan pada pasal 45 yang menyatakan bahwa:

"Orang tua wajib memelihara dan mendidik anak mereka sebaikbaiknya. kewajiban itu berlaku sampai anak itu kawin atau dapat berdiri sendiri meskipun orang tua sudah bercerai.

Penulis berpendapat bahwa hak asuh terhadap anak setelah perceraian tetaplah tanggung jawab kedua orang tua apapun yang terjadi. sepatutnya kedua orang tua diberikan hak di dalam mengasuh. Yang menjadikan mereka kehilangan hak asuhnya jika mereka dicabut dari kekuasaan orang tuanya. Hal itu sesuai Undang-Undang Nomor 1 tahun 1974 Tentang Perkawinan yang mengatakan bahwa anak dibawah usia 18 tahun berada 
dibawah kekuasaan orang tuanya selama mereka tidak dicabut dari kekuasaannya. Oleh karena itu sepanjang orang tua tidak dicabut kekuasaannya, mereka mempunyai hak yang sama di muka pengadilan untuk mengasuh dan mendidik anaknya tanpa dipisah-pisahkan hak asuhnya. (Reza Maulana, 2018)

Undang-Undang Nomor 23 tahun 2002 Tentang perlindungan anak juga mengatakan bahwa orang tua berkewajiban dan bertanggung jawab untuk anaknya. kewajiban ini dijabarkan dengan mengasuh, memelihara, mendidik, dan melindungi anak. Jadi masing-masing orang tua pada prinsipnya memang berhak sepanjang kekuasaan mereka tidak dicabut. Tetapi Undang-undang Nomor 1 tahun 1974 tentang Perkawinan sebelumnya telah menutup kekuasaan orang tua sebagaimana dimaksud pada pasal 47 ayat (1) dengan pasal 41 ayat (1). pasal tersebut mengatakan bahwa bila terjadi perselisihan di dalam penguasaan anak-anak, maka pengadilan yang memutuskan. Kompilasi Hukum Islam selanjutnya disebut KHI mengatur tentang hak asuh anak pasca perceraian. Pengaturan tersebut juga memiliki batasan yang jelas, yaitu berlaku bagi anak yang masih dibawah 12 tahun (belum mummayiz). (Ani Yumarni, 2019)

Pasal 105 KHI menyatakan bahwa pemeliharaan anak yang belum mummayiz atau belum berumur 12 tahun adalah hak ibunya, pemeliharaan anak yang sudah dewasa diserahkan kepada anak untuk memilih diantara ayah atau ibunya sebagai pemegang hak pemeliharaannya, dan biaya pemeliharaan ditanggung oleh ayahnya. (Maswandi, 2017)

Menurut pasal 229 Kitab UndangUndang Hukum Perdata, pengadilan menentukan wali anak dibawah umur. Apabila pihak yang diserahkan sebagai wali kurang mampu membiayai pemeliharaan dan pendidikan anak, maka menurut Pasal 230 b Kitab Hukum Undang-Undang Hukum Perdata hakim dapat menentukan sejumlah uang yang harus dibayar pihak yang lain untuk membayar sejumlah uang untuk membiayai anak dibawah umur. Dalam menyelesaikan suatu perkara, seorang hakim tidak boleh berdalih, dengan alasan tidak ada hukum yang mengatur tentang hal itu. Oleh karena itulah seorang hakim harus menemukan dan menentukan hukumnya. (Suherman, 2019)

Kaidah-kaidah hukum yang diatur dalam Undang-Undang Perkawinan ini disaring mana yang dapat dijadikan suatu hukum yang hidup dan harus dilaksanakan. Dalam penuntutan biaya hidup bagi anak biasanya ibu yang akan bertindak mengajukan tuntutan terhadap bapak (bekas suami) apabila bekas suaminya tidak memenuhi kewajibannya dalam pemberian nafkah hidup bagi anak yang berada dalam asuhannya. Tuntutan yang dilakukan oleh ibu (bekas istri) tidak hanya mengenai pemenuhan terhadap biaya hidup dan pendidikan anak, namun juga menyangkut masalah pemeliharaan anak. Hal seperti ini yang dilakukan oleh Pengadilan Negeri dalam beberapa putusan yang menyangkut masalah pemeliharaan anak, maka setelah bercerai 
dan diputuskan bahwa anak ikut dengan ibunya, maka bekas suaminya akan diberikan kewajiban untuk memberikan nafkah dan biaya pendidikan dan pemeliharaan anak tersebut.

Pengadilan Negeri dalam menyelesaikan kasus-kasus pemeliharaan anak dan tanggung jawab nafkah anak cenderung melimpahkan tanggung jawab pemeliharaan anak kepada ibu kandungnya dan kepada pihak bapak dibebani tanggung jawab untuk memenuhi segala biaya pemeliharaan dan pendidikan anak sehingga anak tersebut dapat berdiri sendiri. Dalam perlindungan anak pasca perceraian tidak hanya sebatas telah terpenuhinya ketentuan Undangundang. Sepanjang orang tua yang telah bercerai dengan sadar dan beritikad baik mau menjalankan kewajibannya sesuai dengan ketentuan yang ada, masalah yang ditimbulkan oleh perceraian, terutama masalah anak, akan dapat diminimalkan.

Mungkin ada anggapan bahwa dengan telah terpenuhinya kebutuhan fisik anak maka masalah perlindungan anak sudah selesai. Tetapi tidak sesederhana itu, sebab dalam kenyataannya walaupun telah ada putusan yang mewajibkan ayah membiayai pemeliharaan anaknya dibelakang hari ayah tersebut tidak peduli lagi dengan kewajibannya. Oleh sebab itu perlu dipikirkan bagaimana upaya untuk mengoptimalkan perlindungan anak pasca perceraian orang tua, yang terutama sekali dengan mengadakan peninjauan kembali terhadap konsep kekuasan orang tua yang bersifat tunggal, serta menegaskan sanksi bagi ayah yang melalaikan kewajiban membiayai pemeliharaan anaknya.

Kalau ibu yang telah diserahi hak pemeliharaan anak ternyata melalaikan kewajibannya maka hukuman baginya adalah mencabut hak pemeliharaan anak atau hak perwalian tersebut melalui permohonan dari pihak yang merasa keberatan dengan tindakan ibu tersebut kepada Pengadilan Negeri. Sesuai dengan makna dan rumusan Undang-Undang, bahwa untuk menentukan hak perwalian, hak pemeliharaan anak yang harus diperhatikan adalah demi kepentingan hukum anaknya. Jadi hakim harus benarbenar memperhatikan apabila anak tersebut dipelihara oleh ibunya atau bapaknya mempunyai jaminan kehidupan sosial dan kesejahteraan yang lebih baik. Hal yang terpenting adalah kemampuan orang tua untuk mengasuh dan memelihara anak.

Dengan demikian, siapa yang nantinya akan memegang hak asuh anak (hadhanah) baik ibu atau ayahnya, yang diutamakan adalah untuk mendukung pertumbuhan yang positif terhadap anak. Bagaimanapun juga meskipun hak asuh anak (hadhanah) hanya bisa pada salah satu orang tuanya namun setelah adanya perceraian kedua orang tuanya masih berkewajiban memelihara dan mengurus anak-anaknya hingga dewasa meskipun tidak tinggal dalam satu rumah. (I Nyoman Sujana, 2017) 
2. Kendala Dalam Pelaksanaan Hak Asuh Anak Setelah Terjadinya Perceraian di Kenagarian Jopang Manganti Kabupaten Lima Puluh Kota

Berdasarkan hasil wawancara dengan Bapak Dodi Dilta sebagai pelaku perceraian, mengenai kendala dalam pelaksanaan hak asuh anak setelah terjadinya perceraian di Kenagarian Jopang Manganti adalah sebagai berikut: Kurangnya rasa tanggung jawab si ibu. Hal ini bisa dilihat pada kenyataannya, walaupun hak asuh anak pada putusan pengadilan Agama Kabupaten Lima Puluh Kota jatuh pada si ibu, tapi tanpa sebab yang jelas si Ibu tersebut menyerahkan anaknya pada Ayah (dikirimkan lewat sopir) atau tanpa menemui Ayahnya, padahal anak di bawah umur (4 tahun) tersebut masih sangat membutuhkan

$\begin{array}{rcrr}\text { Dalam } & \text { Kompilasi Hukum } & \text { Islam } \\ \text { setidaknya } & \text { ada dua } & \text { pasal } & \text { yang }\end{array}$ menentukan pengasuhan anak yaitu Pasal 105 dan 156. Pasal 105 menentukan tentang pengasuhan anak pada dua keadaan. Pertama ketika anak masih dalam keadaan mumayyiz (kurang dari 12 tahun) pengasuhan anak ditetapkan kepada ibunya. Kedua ketika anak tersebut mumayyiz (usia 12 tahun ke atas)dapat diberikan hak kepada anak untuk memilih diasuh oleh ayah atau ibunya. Adapun Pasal 156 mengatur tentang pengasuhan anak ketika ibu kandungnya meninggal dunia dengan memberikan urutan yang berhak mengasuh anak.
Sedangkan dalam Undang-Undang Nomor 3 Tahun 2006 sebagai perubahan atas Undang-undang Nomor 7 Tahun 1989 tidak memberikan perubahan yang berarti mengenai penyelesaian permasalahan pengasuhan anak.

Agama dan Negara seringkali bersekongkol memarginalkan perempuan. Hal itu terlihat jelas dalam Kompilasi Hukum Islam versi Indonesia. Bahkan, sejumlah kajian mengenai perempuan dan hukum di Indonesia menyimpulkan betapa marginalnya posisi perempuan. Indikasi ini membuktikan secara nyata bahwa ketimpangan gender dalam relasi laki-laki dan perempuan di Indonesia masih sangat kuat. Ketimpangan gender jelas merupakan masalah sosial yang harus diselesaikan secara integratif dengan menganalisis berbagai faktor yang turut serta melanggengkannya, termasuk faktor hukum yang kerap mendapat pembenaran agama. (Sulistyowati Irianto: 2006

Pemeliharaan anak menurut gama Islam, sebagai yang kita maklum bersama bahwa kewajiban memelihara, mendidik, dan mengasuh anak adalah menjadi tanggung jawab kedua orang tuanya , hal demikian tentunya kalau kondisi kedua orang tua adalah harmonis akan tetapi jika yang terjadi disharmonisasi kedua orang tuanya (terjadi perceraian), maka siapa yang paling berhak diantara mereka.

Menurut Prof. Dr. Satria Efendi mengatakan bahwa: sebelum mumayyiz adalah masa dimana seorang anak belum dapat membedakan mana yang bermanfaat bagi dirinya dan mana yang 
berharga bagi dirinya. Jika demikian maka tidak diperkenankan memisahkan anak dengan ibunya, jika tidak ingin dipisahkan Allah mengatakan bahwa di hari Kiamat, ibunya lebih berhak selama belum menikah dengan laki-laki lain.

Islam memandang bahwa seorang ibu lebih faham dan mengerti akan kebutuhan anak, hal demikian tentunya jika seorang ibu memenuhi syarat sebagai pengasuh dan pemelihara anak, yang demikian didasarkan pada hadist Abu Hurairah yakni kasus tentang seorang anak yang kedua orang tuanya telah bercerai dimana anak tersebut sudah mampu membantu Ibunya mengambil air dari sumur anak tersebut dipandang nabi sebagai anak yang mumayyiz karena telah dapat membantu ibunya yang pada gilirannya sang anak memilih ibunya.

Syarat-syarat bagi pengasuh anak:

1. Balig, berakal, tidak terganggu ingatan , adil, jujur;

2. Amanah sehingga ada jaminan bagi terpeliharanya anak dengan baik;

3. Mempunyai kemampuan dan kemaun terhadap pekerjaan tersebut;

4. Seorang ibu dapat memelihara anak sekalipun ia telah menikah dengan laki-laki lain sepanjang suami tidak jelas- jelas menolaknya.
3. Solusi Untuk Mengatasi Kendala Dalam Pelaksanaan Hak Asuh Anak Setelah Terjadinya Perceraian di Kenagarian Jopang Manganti kabupaten Lima Puluh Kota

Berdasarkan wawancara dengan Bapak Darispen Datuak Gindo Majo sebagai tokoh agama (ustad) di Kenagarian Jopang Manganti mengenai solusi untuk mengatasi kendala dalam pelaksanaan hak asuh anak setelah terjadinya perceraian di Kenagarian Jopang Manganti adalah sebagai berikut:

1. Terhadap kurangnya rasa tanggung jawab si ibu, maka solusi yang dilakukan adalah memberikan pemahaman kepada si Ibu oleh mamak dipersukuannya akan rasa tanggung jawab bahwa anak tersebut adalah titipan Allah dan akan di pertanggungjawabkan dan anak tersebut diserahkan/diasuh oleh ayahnya.

2. Mengenai kondisi mental si Ibu yang tidak siap menghadapi perceraian, maka solusinya adalah: memberikan kekuatan mental kepada si Ibu yang bisa dilakukan oleh mamak di persukuannya, dengan memberikan pemahaman bahwa tidak setiap perceraian membawa dampak negatif, dan pada kenyataannya anak yang diasuh oleh Ibu apabila terjadi perceraian gagal dalam kehidupannya, bahkan ada orang tua yang single parent berhasil mendidik anaknya.

3. Terhadap Kurangnya pengetahuan agama si Ibu, maka dengan meningkatkan pemahaman agama 
yang dilakukan/diberikan oleh orang yang paham tentang keagamaan (ustad) bahwa Allah telah mentaqdirkan perceraian, maka harus ikhlas menerimanya.

4. Tetap menjalin hubungan yang baik (terjalinnya silaturahmi) antara kedua pasangan yang telah bercerai tersebut walaupun secara hubungan suami isteri sudah tidak ada ikatan lagi. Terhadap semuanya itu dengan meminta bantuan tokoh agama yaitu ataupun mamak dipersukuannya.

Dalam Undang-undang Nomor 1 tahun 1974 pasal 41 Kedua orang tua berkewajiban memelihara dan mendidik anak-anaknya termasuk menyediakan biaya yang dibutuhkan. Pengadilan Agama dapat mencabut hak perwalian apabila ia (orang tua menjadi) pemabuk, penjudi, pemboros, gila melalaikan dan menyalahgunakan hak wewenangnya.

Pasal 49 Undang-undang Nomor 1 tahun 1974 tentang Perkawinan seseorang dapat dicabut kekuasaannya terhadap seorang anak atas permintaan orang tua yang lain apabila:

1. Ia sangat melalaikan kewajibannya terhadap anak-anaknya

2. Berkelakuan buruk;

3. Situasi kondisi pada ibu yang merugikan kepentingan dan kesejahteraan serta membahayakan (Muhamad Ridho, 2016)

Jadi Dalam Kompilasi Hukum Islam setidaknya ada dua pasal yang menentukan pengasuhan anak yaitu Pasal 105 dan 156. Pasal 105 menentukan tentang pengasuhan anak pada dua keadaan yaitu :

1. Ketika anak masih dalam keadaan belum mumayyiz (kurang dari 12 tahun) pengasuhan anak ditetapkan kepada ibunya.

2. Ketika anak tersebut mumayyiz (usia 12 tahun ke atas) dapat diberikan hak asuh kepada anak untuk memilih diasuh oleh ayah atau ibunya.

Adapun Pasal 156 mengatur tentang pengasuhan anak ketika ibu kandungnya meninggal dunia dengan memberikan urutan yang berhak mengasuh anak. Meskipun bentuk formal kehadiran Kompilasi Hukum Islam hanya didukung dalam bentuk Inpres, tidak mengurangi sifat legalitas dan otoritasnya. Karena segala yang dirumuskan di dalamnya, benar-benar sangat dibutuhkan ketertiban masyarakat Islam masa kini dan masa yang akan datang.

Sehubungan tertulis atau tidaknya suatu hukum, sebenarnya hukum itu ada dua kategori, hukum tidak tertulis, dan hukum tertulis. Dengan memperhatikan kategori hukum tersebut, maka Kompilasi Hukum Islam dalam hal ini jelas eksistensinya merupakan hukum tertulis. Dikatakan tertulis sebab sebagian materi Kompilasi Hukum Islam merupakan kutipan dan merujuk pada peraturan perundang-undangan yang berlaku, seperti Undang-undang Nomor 1 Tahun 1974 tentang Perkawinan.

Jadi kunci menang kalahnya seorang ibu dalam perebutan hak asuh anak, karena kurangnya argumentasi hukum si 
ibu untuk meyakinkan hakim tentang pola pengasuhan yang dilakukannya kepada si anak termasuk dalam hal ini perilaku dari orang tua tersebut (seperti si Ibu tidak bekerja sampai larut malam, lebih mengutamakan kedekatan kepada si anak, dibandingkan kesibukan di luar rumah, dsb) serta hal-hal terkait kepentingan si anak secara psikologis, materi maupun non materi, sehingga putusan di sini berdasarkan pada keyakinan hakim maksudnya adalah sesuatu yang diakui adanya berdasarkan pada penyelidikan atau dalil, dan sesuatu yang sudah diyakinkan untuk tidak bias lenyap, kecuali dengan datangnya keyakinan yang lain, atau sesuatu yang menjadi kekuatan atau keputusan hakim didasarkan atau penelitian dari dalil-dalil atau bukti-bukti yang ada, manakala pasangan suami istri bercerai dan si isteri kembali ke agamanya semula. Anak tersebut ditetapkan pengasuhannya kepada pihak ayah dengan pertimbangan untuk mempertahankan akidah si anak.

Dalam era keterbukaan seperti sekarang ini, Sistem Hukum Nasional belumlah tertata secara menyeluruh dan terpadu dengan mengakui dan menghormati hukum agama, hukum adat serta memperbaharui ataupun menyempurnakan peraturan-peraturan warisan hukum colonial maupun hukum nasional yang diskriminatif, sehingga masih dirasakan adanya ketidakadilan gender, kenyataan yang terjadi pada proses penegakan dan penyelesaian masalah hukum terdapat keadaan dimana kepentingan perempuan menjadi termarjinalkan, padahal sesungguhnya dalam teori hukum kepentingan tidaklah berlaku subyektif.

Teori hukum tidak pernah mengarah pada penyelesaian masalah-masalah hukum konkret atau mengategorikan masalah-masalah hukum, melainkan hanya pada upaya mempelajari teknikteknik dan metode yang digunakan dalam dogmatika hukum dan praktik hukum untuk penyelesaian-masalah masalah hukum. ketiadaan perspektif perempuan dan pengabaian pengalaman perempuan dalam struktur pengambilan keputusan, terutama di daerah, mengakibatkan lahirnya produk hukum dan kebijakan yang tidak memperhatikan kepentingan perempuan. Hal yang sama juga terjadi dalam berbagai mekanisme pencarian keadilan informal di mana kultur paruik yang kuat menghalangi akses perempuan untuk memperoleh keadilan. Perempuan dihadapkan pada aturan-aturan adat dan agama yang masih bias gender dan melemahkan posisi perempuan. Posisi perempuan yang masih disubordinasikan sebagai makhluk yang lemah secara intelektual, bawah laki-laki, tidak perlu diikutsertakan dalam pengambilan kebijakan, tidak memiliki pilihan sendiri, tidak dihargai kontribusinya baik dalam ruang privat dan publik, membuatnya menjadi pihak yang terpaksa pasrah ketika berhadapan dengan dominasi patriarki dalam struktur dan budaya di masyarakat.

Jadi menurut Penulis, kenyataan tentang mengenai pemeliharaan anak di bawah umur akibat perceraian anak 
diberikan kepada ayahnya sehingga menyimpang dari ketentuan Kompilasi Hukum Islam pasal 105, karena ketergantungan anak-anak pada ibu terbentuk karena ibu peka menanggapi setiap aktivitas bayi seperti menangis, senyum, menyusu dan manja. Ibu adalah orang yang pertama dan utama yang menjalin ikatan batin dan emosional dengan anak. Hanya ibulah yang bisa dengan cepat mengerti dan mampu menanggapi setiap gerak-gerik bayi. Ibu segera tahu kalau anaknya hendak menangis, senyum atau lapar.

Doktrin dalam aliran psikoanalisis mempengaruhi perkembangan ilmu pengetahuan dan tindakannya sebagai solusi untuk memenuhi kepentingan, mencegah terjadinya tumpang tindih kepentingan, menganggap sebagai pihak ibu yang lebih berperan jika anak masih dibawah umur menjadi pegangan semakin besarnya hak asuh bagi pihak ibu jika terjadi perceraian, bahwa bayi yang berada dalam tahun-tahun yang membutuhkan kelembutan secara umum akan tinggal dengan ibunya, selama tidak ada keberatan terhadap si ibu, bahkan meskipun si ayah tidak bersalah, karena ketidakmampuan ayah untuk memberikan kelembutan secara alamiah dibutuhkan bayi, yang hanya diberikan oleh ibunya

Dengan adanya konsep hak asuh hadhonah dalam KHI tentunya dapat membantu seorang ibu untuk mendapatkan hak asuh anaknya. Namun demikian ketentuan ini tidak berlaku mutlak karena dalam hal Pasal 229 Kompilasi Hukum Islam ditegaskan bahwasanya Hakim dalam menyelesaikan perkara-perkara yang diajukan kepadanya, wajib memperhatikan dengan sungguhsungguh nilai-nilai hukum yang hidup dalam masyarakat sehingga putusannya sesuai dengan rasa keadilan.

Pancasila secara konsep dapatlah disebut sebagai suatu system tentang segala hal, karena secara konseptual seluruh yang tertuang dalam sila berkaitan erat dan saling tidak dapat dipisahkan, suatu kebulatan yang utuh. Keseimbangan yang dijelaskan dalam keseluruhan silanya adalah, keseimbangan antara kepentingan individu dengan kepentingan masyarakat serta kepentingan penguasa, yang dituntun oleh Sila Ketuhanan. Model keseimbangan yang demikian itu pula yang pada dasarnya dikembangkan dalam sistem ketatanegaraan atau pemerintahan Islam ketika masa pemerintahan Rasululah. Keseimbangan individu, masyarakat, penguasa yang dikontrol oleh kehendak illahi. (Ramdan Halim, 2018)

Kesemuanya mengandung beberapa prinsip sebagai berikut:

a. Prinsip-prinsip umat, bahwa orang mukmin adalah umat yang satu, tidak termasuk golongan lain, orang-orang Yahudi dan sekutunya adalah satu umat dengan orang mukmin.

b. Prinsip persatuan dan persaudaraan, yakni persatuan dan persaudaraan seagama maupun persatuan dan persaudaraan sosial, atau persatuan dan persaudaraan kemanusiaan.

c. Prinsip persamaan, yaitu pengakuan hak-hak yang sama antara kaum muslimin dan bukan muslim. 
d. Prinsip kebebasan, Islam memberikan kebebasan dalam banyak hal untuk terpeliharanya masyarakat yang pluralistik.

e. Prinsip hubungan antar pemeluk agama, pemeluk agama baik Islam atau diluar Islam pada dasarnya wajib menjalin hubungan baik dalam berbagai hal.

f. Prinsip hidup bertetangga, orang yang mendapat perlindungan memperoleh hak-hak dan kewajiban yang sama dengan pelindungnya.

g. Prinsip tolong menolong, membela yang lemah dan teraniaya, sebagai aktualisasi adanya kebersamaan dan persahabatan yang haronis.

h. Prinsip perdamaian, perdamaian diantara komunitas muslim, juga perdamaian muslim dengan komunitas lainnya, sebagai implementasi bahwa Islam adalah agama perdamaian.

i. Prinsip musyawarah, adanya kesepakatan dan dapat diterima substansinya oleh semua orang yang mengadakan perjanjian.

j. Prinsip keadilan, perlakuan adil harus diberlakukan pada muslim atau non muslim.

k. Prinsip pelaksanaan hukum, pelaksanaan hukum yang merupakan konsekuensi dari penerimaan terhadap substansi (isi) Konstitusi Medinah sebagai perjanjian yang disepakati dan ditandatangani oleh seluruh kelompok Yahudi.

1. Prinsip kepemimpinan, yaitu posisi Rasulullah, sebagai pemimpin umat juga pemimpin masyarakat yang terdiri dari banyak suku dan agama.

m. Prinsip ketaqwaan, sebuah prinsip yang bersifat horizontal dan vertical dalam Islam. (Maswandi, 2017)

Perkawinan menerangkan tentang adanya kemungkinan orang tua (ayah ibu) atau salah satunya dicabut kekuasaannya untuk waktu tertentu dengan alasan ia sangat melalaikan kewajiban terhadap anaknya atau ia berkelakuan buruk sekali. Hal ini menunjukkan bahwa penetapan pengasuhan anak terhadap salah satu dari kedua orang tuanya bukan merupakan penetapan yang bersifat permanen, akan tetapi sewaktu-waktu hak pengasuhan anak tersebut dapat dialihkan kepada pihak lain melalui pengajuan gugatan pencabutan kekuasaan ke Pengadilan.

Berdasarkan ketentuan tersebut sehingga penetapan hak asuh anak dapat ditetapkan oleh Pengadilan Agama untuk diasuh oleh ibunya dalam jangka waktu tertentu atau sampai anak tersebut berumur 12 tahun dan dapat menentukan sendiri. Sehingga dengan memberikan hak asuh anak di bawah umur 12 tahun oleh Pengadilan Agama sampai jangka waktu yang ditentukan tersebut merupakan suatu Putusan Pengadilan yang berperspektif pada keadilan gender dengan alternatif lain untuk selanjutnya setelah anak berumur 12 tahun maka hak asuh diberikan kepada ayahnya atau menurut pilihan anaknya sendiri sehingga juga tidak melanggar sebagaimana dalam ketentuan Undang-undang Perlindungan Anak. (Reza Maulana, 2018) 
Pertimbangan seperti ini akan memberikan jalan tengah bagi berbagai pihak. Pertama untuk kepentingan anak yang masih kecil di mana masih benarbenar memerlukan kasih sayang ibunya (terutama dalam keadaan balita). Kedua untuk kepentingan ibunya yang secara asasi mempunyai hak yang sama untuk mengasuh anak. ketiga bagi kepentingan ayahnya dalam hal memberikan pendidikan yang Islami, dimana si ayah akan dapat mempergunakan haknya supaya anak tersebut tetap berada dalam ajaran agamanya.

\section{SIMPULAN}

Kesimpulan dari penelitian ini adalah: pelaksanaan hak asuh anak setelah terjadinya perceraian di kenagarian Jopang Manganti pada kenyataannya tidak sesuai dengan putusan Pengadilan agama dengan adanya kendala-kendala, kendala Dalam Pelaksanaan Hak Asuh Anak Setelah Terjadinya Perceraian di Kenagarian Jopang Manganti adalah sebagai berikut: Kurangnya rasa tanggung jawab si ibu, kondisi mental si Ibu yang tidak siap menghadapi perceraian, kurangnya pengetahuan agama si Ibu dan solusi terhadap kendala tersebut adalah: memberikan pemahaman kepada si Ibu akan rasa tanggung jawab bahwa anak tersebut adalah titipan Allah dan akan di pertanggungjawabkan, memberikan pemahaman bahwa tidak setiap perceraian membawa dampak negatif, meningkatkan pemahaman agama bahwa Allah telah mentaqdirkan perceraian.

\section{DAFTAR PUSTAKA}

Mulyadi, 1996, Hukum Perkawinan Nasional, Badan Penerbit, Fakultas Hukum Undip, Semarang

Amir Syarifuddin, 2006, Hukum Perkawinan Islam di Indonesia Antara Figh Munakahat Dan Undang-Undang Perkawinan, Prenada Media, Jakarta.

Fauzi, R. (2018). Dampak Perkawinan Campuran Terhadap Status Kewarganegaraan Anak Menurut Hukum Positif Indonesia. Soumatera Law Review, 1(1), 153. https://doi.org/10.22216/soumlaw.v $1 \mathrm{i} 1.3395$

Maswandi, 2017, Hak Asuh Anak Yang Belum Dewasa Setelah Perceraian, Jurnal Ilmu Pemerintahan dan Sosial Politik, Vol.4 No. 1, hal. 2845;

Hariyani, 2016, Hak asuh Anak Pasca terjadinya Perceraian (studi pada Pengadilan Agama Kota Makasar), Jurnal Pemikiran, Penelitian Hukum, Pendidikan Pancasila dan Kewarganegaraan, Vol.2 No. 2, hal. 45-55;

Reza Maulana, 2018, Kepastian Hukum Terhadap Hukum Terhadap Pengasihan anak Mumayyiz Pasca Perceraraian, Jurnal Yudisial Vol. 11 No. 1 April 2018: hal.55 - 74;

Ramdan Halim, 2018, Akibat Perceraian Terhadap Hak Asuh Anak dan Pengurusan Harta Kekayaan anak oleh orang tua ditinjau dari UU Nomor 1 tahun dan Kompilasi Hukum islam, Jurnal Ilmiah, Jurnal 
Umul Khair: Pelaksanaan Hak Asuh Anak Setelah Terjadinya Perceraian

Kertha Semaya, Vol. 04 No. 05, hal. 28-45

Suherman, A. 2019. Implementasi Independensi Hakim dalam Pelaksanaan Kekuasaan Kehakiman. SIGn Jurnal Hukum, 1(1), 42-51.

Iman Jauhari, 2018, Hak asuh anak pasca terjadimya perceraian orang tua dalam putusan Hakim Mahkamah Syari'ah Banda Aceh, Jurnal Ilmu Hukum Unsyiah, Vol. 4, No. 2, September , Hal. 15-25;

Ani Yumarni, 2019, Perkawinan Bawah Umur dan Potensi Perceraian (Studi Kewenangan KUA Wilayah Kota Bogor, Jurnal Hukum IUS QUIA IUSTUM NO. 1 VOL. 26 JANUARI 2019, Hal. 193 - 211

Nunung Rodliyah, 2014, Akibat Hukum Perceraian berdasarkan UU Nomor 1 TAHUN 1974 Tentang Perkawinan, Jurnal KEADILAN Volume 5 Nomor 1 Maret 2014, Hal.123-135.
Muhamad Ridho, 2016, Itsbat Nikah Terhadap Pelaku Perceraian Diluar Pengadilan dan ImplikasiI Hukumnya (Studi Kasus di Pengadilan Agama Serang), Jurnal Hukum Keluarga Islam, Volume 1 No. 2 (Juli-Desember, hal.22-37

Moh. Afandi, 2018, Hukum Perceraian Di Indonesia: Studi Komparatif antara Fikih Konvensional, UU Kontemporer di Indonesia dan Negaranegara Muslim Perspektif Jurnal Hukum, Vol.XVIII, (No.2), hal. 45-57

Said, M. F. 2018, Perlindungan Hukum Terhadap Anak Dalam Perspektif Hak Asasi Manusia. JCH (Jurnal Cendekia Hukum), 4(1), 141-152.

I Nyoman Sujana, Akibat-Akibat Hukum Perceraian Dalam Perkawinan Campuran, 2017, Jurnal Notariil PISSN: $\quad 2540-797 X, 60 . \quad$ Jurnal Notariil, Vol. 1, No. 2, Mei 2017, hal. 58-67. 